\title{
Influence of the Presence of Muscularis Propria on Recurrence and the Quality of Transurethral Resection in Low-Grade, Stage pTa Bladder Tumors
}

\section{Düşük Dereceli Evre pTa Mesane Tümörlerinde Müskülaris Propria Durumunun Transüretral Rezeksiyon Kalitesi ve Rekürrens Üzerine Etkisi}

\author{
Hakan Türk1, Sıtkı Ün2, Hüseyin Tarhan3, Rauf Taner Divrik4, Ferruh Zorlu3 \\ 1 Dumlupınar University Faculty of Medicine, Evliya Çelebi Training and Research Hospital, Clinic of Urology, Kütahya, Turkey \\ 2Katip Çelebi University Faculty of Medicine, Atatürk Training and Research Hospital, Clinic of Urology, Izmir, Turkey \\ 3 Tepecik Training and Research Hospital, Clinic of Urology, Izmir, Turkey \\ 4 Şifa University Faculty of Medicine, Bornova Training and Research Hospital, Clinic of Urology, Izmir, Turkey
}

What's known on the subject? and What does the study add?

It was pointed out that muscularis propria presence in the pathology specimens of low-grade stage pTa tumours is an indicator of a high quality transurethral resection.

\begin{abstract}
Objective

Transurethral resection (TUR) of the bladder and intravesical chemotherapy is the standard treatment option for non-muscle-invasive bladder tumors. Inadequate tumor resection results in early recurrence and staging inaccuracies, which all will change the course of the disease. High-quality TUR treatment is therefore an important factor in the treatment of non-muscle-invasive bladder tumors. In this study, we investigated the significance of detecting the presence of muscularis propria (MP) in pathology specimens of low-grade, stage pTa tumors in patients who were treated with TUR due to primary bladder tumors, with regard to recurrence, time to recurrence and progression.
\end{abstract}

\section{Materials and Methods}

Initially, 841 patients who were treated with TUR due to primary bladder tumors were enrolled in the study. A total of 597 patients were excluded from the study because they failed to meet the study criteria. Group 1 consisted of patients with MP detected in the pathology specimens; whereas group 2 consisted of patients whose TUR specimens did not include MP. The patients were evaluated with regard to gender, tumor number, presence or absence of MP, and recurrence status.

\section{Results}

MP was observed in only $14(15.2 \%)$ of 92 patients with recurrence, but not in the remaining $78(84.8 \%)(p=0.004)$. Progression occurred in 4
Öz

Amaç

Yeni kasa invaze olmayan mesane tümörlerinin standart tedavisi mesanenin transüretral rezeksiyonu (TURM) ve intravezikal kemoterapidir. Yetersiz tümör rezeksiyonu, erken nüks ve düşük evreleme gibi hastalığın seyrini değiştirecek durumları ortaya çıkarmaktadır. Bu nedenle kasa invaze olmayan mesane tümörlerinin tedavisinde kaliteli TURM önemli bir faktördür.

Gereç ve Yöntem

Primer mesane tümörü nedeniyle TURM olmuş 841 hasta çalışmaya alındı. Toplam 597 hasta bu kriterlerimize uymadığı için çalışmadan çıkarıldı. Grup 1'de patoloji spesmeninde müskülaris propria (MP) görülen hastalar bulunurken; grup 2, TURM örneğinde MP görülmeyen hastalardan oluşmuştur. Hastalar; cinsiyet, tümör sayısı, patoloji spesmenindeki tümör hacmi, MP durumu, nüks durumu, nüks zamanı ve progresyon açısından değerlendirildi.

Bulgular

Nüks eden 92 hastanın sadece 14 'ünde $(\% 15,2)$ MP bulunurken geriye kalan $78(\% 84,8)$ hasta da MP görülmemiştir $(p=0,004)$. Grup 1'de progrese olan hasta $4(\% 14,2)$, grup 2'de $28(\% 29)$ hasta olarak ortaya çıkmıştır $(p=0,159)$. Tek değişkenli analizde, tümör multiplitesi $(p=0,003)$ ve MP yokluğu $(p=0,004)$ rekürrens üzerine etkili bulunmuştur. Çok değişkenli analizde yine bu iki parametre nüks üzerine etkili bulunmuştur $(p=0,004)$. 


\section{ABSTRACT}

(14.2\%) patients of group 1 and $28(29 \%)$ patients of group 2 ( $p=0.159)$. In univariate analysis, tumor multiplicity $(p=0.003)$ and the absence of MP $(p=0.004)$ were found to have effects on recurrence. In multivariate analysis, these two parameters were also found to be have effects on recurrence $(p=0.004)$.

\section{Conclusion}

In this study, it was pointed out that MP presence in the pathology specimens of low-grade stage pTa tumors is an indicator of a high quality TUR and, a well-done TUR is important for the prevention of recurrence.

\section{Keywords}

Bladder tumor, recurrence, tumor volume, muscularis propria

\section{ÖZ}

Sonuç

Bu çalışmada düşük dereceli evre pTa tümörlerin patoloji örneklerinde MP varlığının kaliteli bir TURM'nin göstergesi olduğu ve nüksleri önlemede iyi yapılmış TURM'nin önemine dikkat çekilmiştir.

\section{Anahtar Kelimeler}

Mesane tümörü, rekürrens, tümör hacmi, müskülaris propria

\section{Introduction}

The risk of bladder cancer increases particularly with age in industrial societies. In approximately $75 \%$ of patients, the bladder tumors are confined to the mucosa [stage pTa, carcinoma in situ (CIS)] or submucosa (pT1) at the time of diagnosis (1). Bladder tumor ranks $7^{\text {th }}$ among all malignancies in men, whereas $17^{\text {th }}$ in women (2). Worldwide the incidence is 9 in hundred thousand in men and 2 in hundred thousand in women $(2,3)$.

The established standard treatment for non-muscle-invasive bladder tumors is transurethral resection (TUR) of the bladder and intravesical chemotherapy. The primary objectives of TUR are; (i) to remove all visible tumors, (ii) to ensure an accurate pathological tumor staging and grading and (iii) to determine the clinically significant prognostic factors $(4,5)$. However, these objectives may not always be achieved due to; (i) bad cystoscopic image, (ii) a large tumor, (iii) multiple tumors, (iv) difficult localization, and (v) bleeding and perforation (6). As a result, consequences may occur that change the course of the disease, such as inadequate resection of the tumor, early recurrence and staging inaccuracies.

Residual tumor after TUR can be seen as high as 64\% (7), and the recurrence rate at the first cystoscopy as 70\% (8). Although these figures vary between clinics, this variance was attributed to the quality of TUR and the importance of high quality TUR was underlined in the study by The European Organisation for Research and Treatment of Cancer (EORTC) (9). The recurrence after first cystoscopy is rather attributed to the quality of previous TUR and overlooked tumor cells rather than tumor biology $(6,9,10)$. Mariappan et al. (11) have shown in their study that the presence of MP in TUR specimens was a marker indicating the quality of TUR and experience of the surgeon. Highquality TUR is therefore an important factor in the treatment of nonmuscle-invasive bladder tumors. In this study, we investigated the significance of detecting the presence of MP in pathology specimens of low-grade, stage pTa tumors in patients treated with TUR due to primary bladder tumors, with regard to recurrence, time to recurrence and progression.

\section{Materials and Methods}

A total of 841 patients, who underwent TUR treatment for primary bladder tumors in our clinic between January 2000 and December 2013, were enrolled in the study. Prior to TUR operation, urinary cytology was carried out as a standard procedure in our clinic, and afterwards, the tumors in the bladder were mapped with 30-degree and 70-degree optical angles and the detected tumors were completely resected with bipolar or monopolar TUR resection. Smaller tumors were resected en bloc and resection of larger tumors were performed in fractions. Then, the tumor base and tumor side were sampled separately and sent to pathology in separate containers. If there was no bleeding or any sign of perforation and a complete tumor removal was deemed, then a single dose of Epirbucin was given intravesically within the first 6 hours. When the pathological investigation revealed stage pT1, high-grade tumor or incomplete resection was suspected, then repeat TUR (reTUR) was planned within 2-6 weeks Then, risk stratification of patients was performed and intravesical mitomycin $\mathrm{C}$ or Bacillus Calmette Guarin (BCG) treatment was planned. Exclusion criteria of this study were: patients with pathologic stage pT1, pT2 and CIS, suspected of incomplete TUR, those who missed postoperative a single dose of intracavitary chemotherapy, and failed to show up at regular cystoscopy follow-up. Although we normally plan intravesical mitomycin C or BCG treatment according to risk stratification in routine application, some patients cannot receive this treatment due to social reasons or because they cannot obtain these drugs. In order to exclude the effects of intracavitary treatment on recurrences, patients, who had received intravesical chemotherapy before the first cystoscopy, were also excluded from the study. Based on the aforementioned criteria, a total of 597 patients were excluded from the study. We have included 244 patients who met the inclusion criteria of the study e.g., having low-grade pTa as the result of first TUR, post-operative single dose intravesical chemotherapy and complete TUR. The patients were divided into two groups: Group 1 included patients whose pathology specimens revealed MP; whereas group 2 consisted of patients without MP in TUR specimens. The patients were evaluated with respect to gender, the number of tumors, tumor volume in pathological specimens, MP status, recurrence status, time to recurrence, and progression. Unlike other studies, instead of tumor size, tumor volume in pathological specimens was used in this study. Univariate and multivariate logistic regression analysis and t-test were used to show the relationship between the variables. All statistical analyses were performed using SPSS version 13.0 (Chicago, IL, USA). A $p$ value of 0.05 was considered statistically significant. 


\section{Results}

Out of 244 patients, 220 (90.1\%) were male, 24 (9.9\%) were female, and the average age was 60 (24-82) years. MP was observed in 52 (21.3\%) patients (group 1) while not in 192 (78.7\%) patients (group 2). Recurrence occurred in 28 (53.8\%) of 52 group 1 patients, and 156 $(81.2 \%)$ of 192 group 2 patients $(p=0.004)$. Median time to recurrence was 34.4 months in group 1 and 41.1 months in group $2(p=0.218)$. Out of 184 patients having recurrence, only 28 (15.2\%) displayed MP, while the remaining $156(84.8 \%)$ did not $(p=0.004)$. Progression was detected in $8(14.2 \%)$ patients of group 1 and 56 (29\%) patients of group 2 ( $p=0.159)$. Time to progression was 29.7 and 41.7 months in groups 1 and 2, respectively ( $p=0.488$ ). No difference was observed in terms of tumor multiplicity between the two groups $(p=0.479)$; the mean tumor volume was found to be $2.8 \mathrm{cc}$ in group 1, and $1.6 \mathrm{cc}$ in group $2(p=0.001)$. The mean follow-up period was 110.3 months in group 1, and 116.2 months in group $2(p=0.135)$. The tumor was found to be solitary in 28 patients of group 1 and in 24 patients of group 2 ( $p=0.472)$ (Table 1).

In univariate analysis, tumor multiplicity ( $p=0.003)$ and MP absence $(p=0.004)$ were found to be influential on recurrence. In multivariate analysis, again these two parameters were found to have an effect on recurrence $(p=0.004)$ (Table 2$)$. Considering the factors influencing progression, only tumor volume was observed to be significant according to univariate analysis $(p=0.005)$ (Table 3$)$. In the subgroup analysis of patients with solitary tumor $(n=116)$ upon univariate analysis, MP $(p=0.003)$ and tumor volume $(p=0.003)$ were found to have an effect on recurrence. When these figures were used in multivariate analysis, again MP $(p=0.002)$ and tumor volume $(p=0.019)$ were found have an effect (Table 4).

\section{Discussion}

An accurate histopathological evaluation and resection of the apparent tumor are intended by TUR in bladder tumors $(4,5)$. Smaller tumors are removed by en bloc resection, for larger tumors, however, resection is recommended in fractions (3). It should be noted that TUR is an oncologic surgery and the principles of major operations should be taken into consideration for TUR as well. High-quality TUR has been first suggested in studies conducted by the EORTC, and its impact on the accurate staging and subsequent recurrence has been highlighted (9). Considering particularly the fact that about $75 \%$ of patients have non-muscle-invasive bladder tumor which can be completely cured by a quality TUR; the importance of the procedure is manifested (6). The EORTC has related the best indicator of the TUR quality with early recurrence rates and reported the factors affecting early recurrence as overlooked tumor during TUR and inadequate tumor resection (9).

Mariappan et al. (6) have demonstrated that (i) multiplicity, (ii) stage and (iii) MP presence of the tumor are the factors influencing recurrence in the first cystoscopy after TUR. In their study, Herr and Donat (12) have highlighted the importance of MP presence for the quality of TUR. Another similar study has stated that MP presence in the specimen submitted to pathology is an indicator of TUR quality $(6,11)$. In a study by Mariappan et al. $(6)$, tumor was shown to occur in the first cystoscopy in $69.6 \%$ of patients with non-MP pathology and in $39.1 \%$ of patients with MP pathology and these results were

Table 1. Demographic data and distribution of patients in both groups

\begin{tabular}{|c|c|c|c|c|}
\hline & Group $1(\mathrm{MP}+)(\mathrm{n}=52)$ & Group $2(\mathrm{MP}-)(\mathrm{n}=192)$ & Total/mean & $p$ value \\
\hline Male (n) & 48 & 180 & 228 & 0.808 \\
\hline Female (n) & 4 & 12 & 16 & 0.794 \\
\hline Age (year) & 61.8 & 54.3 & 56 & $0.003^{*}$ \\
\hline Recurrence (+) (n) & 28 & 156 & 184 & $0.004^{*}$ \\
\hline Time to recurrence (month) & 34.4 & 41.1 & 40.4 & 0.218 \\
\hline Progression (+) (n) & 8 & 56 & 64 & 0.159 \\
\hline Time to progression (month) & 29.7 & 41.7 & 40.2 & 0.488 \\
\hline Solitary tumour (n) & 28 & 88 & 116 & 0.472 \\
\hline Multiple tumours (n) & 24 & 104 & 128 & 0.479 \\
\hline Tumour volume (cc) & 2.8 & 1.6 & 1.8 & $0.001^{*}$ \\
\hline Follow-up period (month) & 110.3 & 116.2 & 113.6 & 0.135 \\
\hline
\end{tabular}

Table 2. Factors influencing recurrence

\begin{tabular}{|l|l|l|l|l|}
\hline & Recurrence $(+)(n=184)$ & Recurrence $(-)(n=60)$ & $p$ value (univariate) & $p$ value $($ multivariate) \\
\hline Gender M/F $(n)$ & $180 / 4$ & $48 / 12$ & 0.978 & 0.003 \\
\hline Multiple tumour $(n)$ & 76 & 52 & $0.003^{*}$ & \\
\hline Tumour volume (cc) & 1.8 & 1.7 & 0.687 & 0.004 \\
\hline MP absence $(n)$ & 156 & 36 & $0.004^{*}$ & 0.06 \\
\hline Age (year) & 56.2 & 54.9 & & \\
\hline M: Male, F: Female, MP: Muscularis propria & &
\end{tabular}


found to be statistically significant. In this study, recurrence was shown to occur in the first cystoscopy in $84.7 \%$ of patients with nonMP pathology and in 60\% of patients with MP pathology and, these results were found to be statistically significant.

The rate of absence of MP ranged between 30\% and 50\% in published series $(13,14)$. High residual tumor rate and tumor upstaging rates of 40-51\% were observed in non-MP stage pT1 patients $(14,15,16,17)$. The absence of MP has been shown to be associated with increased risk of early recurrence, even in low-grade pTa tumors (6). Jesuraj et al. (18) has demonstrated MP presence in $45.8 \%$ of TUR applications of inexperienced surgeons and 67.3\% of experienced surgeons and argued that the presence of MP is an indicator of surgeon's experience and the quality of TUR. In addition, Mariappan et al. (6) showed that higher rates of MP was detected in TUR applications performed by experienced surgeons and, an inexperienced surgeon was recognized as an independent risk factor for early recurrence. In this study, MP presence was reported to be the most powerful factor for early recurrence. The high rate of MP even in TUR performed by experienced surgeons proves the importance of TUR quality. In our study, upstaging was not assessed because our series were stage pTa patients. We do not perform re-TUR in these patients.

Treatment plan for bladder tumor patients is formed according to TUR pathology and depth of invasion. For this reason, the guidelines, while recommending high quality TUR, describe TUR quality as the presence of MP in pathology specimen (13). All the studies have shown that lower pathological staging and residual tumor are not rare and, thus, a well-done TUR is significant for local recurrence and therapy management of the patient (19). All the relevant studies emphasize the impact of quality of TUR on the patient's recurrence and progression. One of these studies is the one by Badalato et al. (19) with 114 patients having high-grade T1. In this study, the first TUR pathological specimens in high-grade stage pT1 patients, who have undergone radical cystectomy, were examined and in 78\% of the patients whose pathology showed no MP were identified as low-

\section{Table 3. Factors influencing progression}

\begin{tabular}{|l|l|l|l|}
\hline & $\begin{array}{l}\text { Progression (+) } \\
(\mathrm{n}=64)\end{array}$ & $\begin{array}{l}\text { Progression (-) } \\
(\mathrm{n}=180)\end{array}$ & $\begin{array}{l}\text { p value } \\
\text { (univariate) }\end{array}$ \\
\hline Gender M/F (n) & $60 / 4$ & $168 / 12$ & 0.082 \\
\hline Multiple tumour (n) & 32 & 96 & 0.092 \\
\hline Tumour volume (cc) & 1.18 & 2 & $0.005^{*}$ \\
\hline MP absence (n) & 56 & 136 & 0.159 \\
\hline Age (year) & 59 & 54 & 0.576 \\
\hline M: Male, F: Female, MP: Muscularis propria \\
\hline
\end{tabular}

staging and, eventually, the presence of MP in TUR specimens was emphasized as predicting low staging.

In the present study, recurrence, time to recurrence, progression, and time to progression were evaluated according to MP presence in pathological specimens of the patients who were treated with TUR due to a newly diagnosed bladder tumor and whose pathology results revealed low-grade stage pTa. Patients who had a history of a previous TUR, high-grade tumor and intravesical therapy were excluded from the study in order to establish a homogeneous group of patients and to avoid the effect of intravesical treatment on recurrence. In univariate and multivariate analyses, in accordance with the literature, the presence of tumor multiplicity and MP presence were determined as the factors predicting recurrence $(6,11,12,15,20,21)$. Recurrence has been shown to be statistically significantly more frequent in patients with non-MP (Table 2). Considering the subgroup analysis in patients with a solitary tumor by excluding patients with multiple tumors, the absence of MP was determined to be a predictive factor for recurrence. The effect of MP absence on time to recurrence, progression and time to progression was not statistically significant. We believe that studies with larger series are required for the significance of these values. Evaluation of the MP status in patients with solitary and multiple tumors, however, displayed no statistically significant difference in terms of the presence of MP between these two groups.

When we evaluated our results in the light of the literature, the presence of MP in TUR was found to affect the quality of TUR and probability of following recurrences positively.

Although lamina propria is not invaded by pTa tumors, the effect of MP presence on recurrence should be attributed to the fact that MP presence is an indicator of the quality of TUR and, in turn, the effect of high quality TUR on recurrence. In our study, instead of tumor size in cystoscopy, the volume of the pathological specimen was considered as the tumor burden. We believe that tumor size does not provide an accurate prediction cystoscopically. Large-scale studies are needed to evaluate our prediction.

In our study, the number of patients in group 1, namely patients with MP in pathology specimens, was found to be quite low when compared with the literature $(21 \%)(13,14)$. We attribute this result to the problems in the assistant training in our clinic. Nonetheless, we believe that TUR training should be held in the later years of the specialization period and in a controlled manner because this low rate may adversely affect our oncologic results.

Being a retrospective study besides the small number of patients in group 1 are the prominent limiting factors of our study. However, this is the first study which excluded the effects of intravesical chemotherapy on recurrence, which is a prominent feature.

Table 4. Factors influencing recurrence in patients with solitary tumour

\begin{tabular}{|l|l|l|l|l|} 
& Recurrence $(+)(n=36)$ & Recurrence $(-)(n=22)$ & $p$ value (univariate) & $p$ value (multivariate) \\
\hline Gender M/F (n) & $60 / 12$ & $20 / 4$ & 0.268 & 0.571 \\
\hline Multiple tumour (n) & 1 & 1.5 & $0.029^{*}$ & $0.019^{*}$ \\
\hline Tumour volume (cc) & 40 & 24 & $0.003^{*}$ & $0.002^{*}$ \\
\hline MP absence (n) & 51.1 & 56.3 & $0.003^{*}$ & \\
\hline M: Male, F: Female, MP: Muscularis propria
\end{tabular}




\section{Conclusion}

In conclusion, according to our study, the presence of MP in the pathological results of low-grade stage pTa tumors is an indicator of a quality TUR, and in turn, a well done TUR is important in the prevention of recurrences. If our findings would be supported by new studies conducted by larger patient series, this will probably demonstrate the need for reTUR for non-MP stage pTa patients as well, as it is for stage pT1 bladder tumors.

\section{Ethics}

Ethics Committee Approval: Ethics committee approval was not obtained because this was a retrospective study, Informed consent: Written informed consent was not obtained from patients because this was a retrospective study, Peer-review: Internal peer-reviewed.

\section{Authorship Contributions}

Concept: Hakan Türk, Ferruh Zorlu, Design: Hakan Türk, Sıtkı Ün, Ferruh Zorlu, Data Collection or Processing: Hakan Türk, Sıtkı Ün, Analysis or Interpretation: Sıtkı Ün, Hüseyin Tarhan, Rauf Taner Divrik, Literature Research: Hakan Türk, Sıtkı Ün, Writing: Hakan Türk. Conflict of Interest: No conflict of interest was declared by the authors. Financial Disclosure: The authors declared that this study has received no financial support.

\section{References}

1. Burger $M$, Catto JW, Dalbagni G, Grossman HB, Herr H, Karakiewicz $P$, Kassouf W, Kiemeney LA, La Vecchia C, Shariat S, Lotan Y. Epidemiology and risk factors of urothelial bladder cancer. Eur Urol 2013;63:234-241.

2. Ferlay J, Soerjomataram I, Dikshit R, Eser $S$, Mathers $C$, Rebelo $M$, et al. GLOBOCAN 2008 v1.2, Cancer Incidence and Mortality Worldwide: IARC CancerBase No. 10 2010, International Agency for Research on Cancer: Lyon, France. http://www.iarc.fr/en/publications/eresources/cancerbases/ index.php

3. Babjuk M, Oosterlinck W, Sylvester R, Kaasinen E, Bohle A, Palou-Redorta $\mathrm{J}$; European Association of Urology (EAU). EAU guidelines on non-muscleinvasive urothelial carcinoma of the bladder. Eur Urol 2008;54:303-314.

4. Babjuk M. Transurethral resection of non-muscle invasive bladder cancer. Eur Urol 2009;8(Suppl):542-548.

5. Carmack AJ, Soloway MS. The diagnosis and staging of bladder cancer: from RBCs to TURs. Urology 2006;67(Suppl 3):3-8.

6. Mariappan P, Finney SM, Head E, Somani BK, Zachou A, Smith G, Mishriki SF, N'Dow J, Grigor KM; Edinburgh Urological Cancer Group. Good quality white-light transurethral resection of bladder tumours (GQ-WLTURBT) with experienced surgeons performing complete resections and obtaining detrusor muscle reduces early recurrence in new non-muscle-invasive bladder cancer: validation across time and place and recommendation for benchmarking. BJU Int 2012;109:1666-1673.

7. Brauers $A$, Buettner $R$, Jakse $G$. Second resection and prognosis of primary high risk superficial bladder cancer: is cystectomy often too early? J Urol 2001;165:808-810.

8. Kurth K. Natural history and prognosis of untreated and treated superficial bladder cancer. Oxford, UK: Isis Medical Media; 1997.

9. Brausi $M$, Collette $L$, Kurth $K$, van der Meijden AP, Oosterlinck W, Witjes JA, Newling D, Bouffioux C, Sylvester RJ; EORTC Genito-Urinary Tract Cancer Collaborative Group. Variability in the recurrence rate at first follow-up cystoscopy after TUR in stage Ta T1 transitional cell carcinoma of the bladder: a combined analysis of seven EORTC studies. Eur Urol 2002;41:523-531.

10. Mariappan P, Smith G, Lamb AD, Grigor KM, Tolley DA. Pattern of recurrence changes in noninvasive bladder tumours observed during 2 decades. J Urol 2007;177:867-875.

11. Mariappan P, Zachou A, Grigor KM; Edinburgh Uro-Oncology Group. Detrusor muscle in the first, apparently complete transurethral resection of bladder tumour specimen is a surrogate marker of resection quality, predicts risk of early recurrence, and is dependent on operator experience. Eur Urol 2010;57:843-849.

12. Herr HW, Donat SM. Quality control in transurethral resection of bladder tumours. BJU Int 2008;102:1242-1246.

13. Maruniak N, Takezawa K, Murphy WM. Accurate pathological staging of urothelial neoplasms requires better cystoscopic sampling. J Urol 2002;167:2404-2407.

14. Dalbagni G, Herr HW, Reuter VE. Impact of a second transurethral resection on the staging of $\mathrm{T} 1$ bladder cancer. Urology 2002;60:822-824.

15. Grimm MO, Steinhoff $C_{1}$ Simon $X_{1}$ Spiegelhalder $P_{1}$ Ackermann $R$, Vogeli TA. Effect of routine repeat transurethral resection for superficial bladder cancer: a long-term observational study . J Urol 2003;170:433-437.

16. Herr HW. The value of a second transurethral resection in evaluating patients with bladder tumours. J Urol 1999;162:74-76.

17. Dutta SC, Smith JA Jr, Shappell SB, Coffey CS, Chang SS, Cookson MS. Clinical under staging of high risk nonmuscle invasive urothelial carcinoma treated with radical cystectomy. J Urol 2001;166:490-493.

18. Jesuraj MG, Harris M, Rogers A, Whiteway JE. Completeness of the first resection of bladder tumour depending on the seniority of the surgeon. Eur Urol 2008;7(Suppl 3):269.

19. Badalato G, Patel T, Hruby G, McKiernan J. Does the presence of muscularis propria on transurethral resection of bladder tumour specimens affect the rate of upstaging in cT1 bladder cancer? BJU Int 2010;108:12921296.

20. Divrik T, Yildirim U, Eroğlu A, Zorlu F, Ozen H. Is a second transurethral resection necessary for newly diagnosed pT1 bladder cancer? J Urol 2006;175:1258-1261.

21. Jakse G, Algaba F, Malmstrom PU, Oosterlinck W. A second-look TUR in T1 transitional cell carcinoma: why? Eur Urol 2004;45:539-546. 